\title{
The Implementation of Blended Learning in Teaching English at Senior High School in Sidoarjo
}

\author{
Anita Firdaus $^{1}$, Yuli Astutik ${ }^{2}$ \\ ${ }^{1,2}$ Universitas Muhammadiyah Sidoarjo \\ *Corresponding Author: yuliastutik@umsida.ac.id
}

\begin{abstract}
Blended learning is a learning strategy that combines face-to-face learning (both traditional inclass and virtually with video conferences) with online learning (e-learning). Blended learning is used as the best solution for dealing with restrictions on large-scale activities in Indonesia due to the spread of the coronavirus. SMAN 1 Porong applies blended learning to ensure the teaching and learning process continues, especially in learning English. On the other hand, teachers in this school face challenges in implementing blended learning. Therefore, the purposes of this study are to reveal in detail the implementation of blended learning and the challenges faced by teachers using case study research. To collect data, the researchers used observation and unstructured interview techniques. The results of this study indicate that SMAN 1 Porong has successfully implemented blended learning, especially for English lessons. However, the English teachers at the school are not free from challenges, such as the difficulty of finding the right strategy for face-to-face and online classes. This study implies that, however, the success of blended learning must be accompanied by teachers' creativity in teaching both face-to-face and online and the support of school facilities.
\end{abstract}

Keywords: Teaching English, Blended Learning, Senior High School

\section{INTRODUCTION}

Blended learning is a type of learning that seamlessly integrates face-to-face instruction with online instruction. Experts share their thoughts on blended learning, claiming that it is the only effective teaching technique that combines technology in its execution (Dziuban et al., 2018; Galvis, 2018; Kumar et al., 2021; Menon, 2019). Blended learning combines two fields of study: education and the application of educational technologies (Chew et al., 2008; Zhang, 2020). Additionally, blended learning is a type of education that involves merging, mixing, and integrating traditional and digital-based education systems. Thus, blended learning is defined as a combination of face-to-face learning (either offline in class or synchronously with video conferencing) and online learning that utilizes technology, for instance, Google Classroom, Moodle, or Spada (Husamah, 2014; Ma'rifatulloh, 2020).

The teaching and learning process will be more meaningful for both the teachers and the students if the teachers are innovative in their usage of blended learning (Crawford \& Jenkins, 2017; Evain \& Marco, 2018; Susanti \& Prameswari, 2020). The following are five key components in blended learning (Carman, 2002): The first is a live event showing that both teachers and students are actively involved in the learning process. The second includes material obtained through the internet. This is based on the student's personal experience. Then the third is collaboration, where teachers and students actively communicate to create 
collaborative learning activities such as discussions, asking and answering questions, and other class activities. The fourth is evaluation, meaning that teachers must assess students' knowledge. Teachers can conduct an assessment before or after the learning process to see whether the material presented by the teacher can be accepted by the students well or vice versa. The last one is a reference to supporting blended learning. Students will be taught to look for references for face-to-face studies (traditional face-to-face in the classroom or synchronous with video conferences) and online learning as a means of supporting the material. They can look it up on the internet or in books about the material being taught to students at that time (Alsalhi et al., 2019).

Furthermore, Khan (2010) offers a blended learning framework as a guide to plan the teaching and learning process in online or face-to-face classes. This framework enables the development of teaching and learning process models, material delivery, learning process management for the students, and blended learning programs evaluation. According to Khan, a variety of factors are required to create an effective learning environment in a school, which for the framework has five dimensions: Pedagogical, Technological, Interface Design, Resource Support, and Management. First, the pedagogical dimension is the combination of the content that the teacher has to deliver to the students (content analysis), the students' needs (learner analysis), and the learning objectives (goal analysis), which also explains the strategy that teachers use in e-learning. Secondly, the technological dimension is an issue in how the teachers create a learning environment for the learners and the tools that the teachers use to deliver the learning process. We can call it the learning management system (LMS) that the teachers employed in the class. Some technological accesses are required to support the learners, such as application access and accessibility issues. Thirdly, the interface design component addresses how blended learning can benefit from interaction design. The design phase must be sufficiently advanced to facilitate the learning process. As a result, interfacerelated concerns such as content structure and learning models must be evaluated. Then there is the resource support dimension, which is concerned with the materials that teachers and students use for face-to-face and online classes, which may include a tutor for the learners via e-mail, chat, or other available means. Finally, the management component addresses the management of blended learning processes, including infrastructure and delivery kinds for teachers and students. The management dimension also discusses registration, notification, and scheduling in the use of blended learning. Therefore, this study uses the framework offered by Khan (2010) because it is judged to be in accordance with existing conditions.

Adi and Fathoni (2020) conducted a study on the Analysis of Blended Learning for Indonesian Sports Schools. The outcomes of their study indicated that implementing blended learning benefited student learning and that the majority of students preferred it since it simplifies access to content. While children must attend school for training and compete in contests held outside of the city, tasks were simplified. In contrast to Adi and Fathoni, who focus on the use of blended learning in sports education, Ma'rifatulloh (2020) examined the extent to which blended learning impacts students' writing skills in the context of EFL at the college level. The result showed no significant difference between conventional classes conducted face-to-face regularly in the classroom and online learning through Moodle combined with Google Docs. Therefore, Ma'rifatulloh (2020) stated that blended learning is an alternative way of teaching English. Hence, this research tries to carry out the same case as previous studies of Ma'rifatulloh's. This research also focuses on blended learning in the context of EFL, especially at the senior high school level in Indonesia. Whereas previous research used quantitative data to determine the effectiveness of blended learning, the 
researchers in this study used qualitative data because blended learning has been a phenomenon that already existed in the field. Teachers and students have experimented with blended learning in school and other pursuits. Its utilization will provide the learner with a novel experience in learning the lesson and positive effects (Christopoulos \& Sprangers, 2021). Blended learning is a potential way to enhance the learning experience by changing learning methods to be more adaptive to the changing world. Therefore, teachers must adapt their teaching better to follow developments that occur.

On September 10th, 2020, a pre-observation conducted by researchers at SMA Negeri 1 Porong, Sidoarjo revealed that the school had used blended learning, which combines faceto-face learning in the classroom (and also synchronous with Google Meet) and online learning by using Google Classroom. From interviews with principals and teachers in schools conducted by researchers in this study, it was known that the school had combined face-to-face and online learning, including for teaching the English language. According to Tayebinik and Puteh (2013), blended learning is a strategy spreading in the world of teaching that combines traditional classroom teaching with online learning. In line with that, this research aims to investigate the use of blended learning in teaching English. It will demonstrate how blended learning is used in the classroom to teach English. Therefore, the research questions of this study are:

1. How is the implementation of blended learning in English teaching at Senior High School in Sidoarjo?

2. What are the teacher's challenges in implementing blended learning in English teaching at Senior High School Sidoarjo?

\section{METHOD}

The data for this study was collected using a qualitative descriptive design. According to Creswell et al. (2007), a qualitative method describes and elucidates an object in greater detail. It means that the researcher must describe and explain her study's findings based on naturally occurring conditions in the school without being modified.

The research subjects of this study were two English teachers and two students at SMA Negeri 1 Porong in the academic year 2020/2021. Researchers obtained the data using two methods: observation and interviews. The researcher began observing on February 17th, 2021, and continued till April 17th, 2021. The data were collected through observation and nonparticipant methods, and the answer came from the usage of blended learning in English education. The researchers, as impartial observer, is not directly participating in the activities observed at the time, which is why observation as a non-participant was chosen. The results corroborated the researchers' findings based on observations and conversations with the research participants. In the interview, the researchers employed unstructured interviews to obtain data about the application of blended learning in English instruction during the interview session. The unstructured interview's goal was to focus on the application of blended learning in English teaching. Two English teachers and two pupils participated in this interview, which included casual questions and conditions.

Then in analyzing the data, the researchers used descriptive analysis with several steps; First, to answer research question 1, the researchers reviewed the observation records and classified them according to five components based on Khan's framework (2010). Then, to answer research question 2 , the researchers transcribed the interview data and analyzed it based on the research objectives to the teacher's challenges in implementing Blended Learning. The 
researchers then carry out the reduction process to verify the validity of the existing data. Finally, the researchers wrote reports and conclusions based on the information gathered.

\title{
FINDINGS AND DISCUSSION
}

In this session, the researchers explain the implementation of blended learning at SMAN 1 Porong Sidoarjo using the Khan (2010) framework, which has five dimensions: Pedagogical, Technology, Interface Design, Resource Support, and Management. Other than that, the researcher will mention the challenges faced by teachers in teaching English using blended learning.

\section{THE IMPLEMENTATION OF BLENDED LEARNING IN ENGLISH TEACHING AT SENIOR HIGH SCHOOL PORONG SIDOARJO}

\author{
PEDAGOGICAL IN BLENDED LEARNING FOR TEACHING ENGLISH
}

The pedagogical aspects explain the material delivered to the students and analyze the learners' needs and the learning objectives. In the observation results, in regards to the online learning, the researchers found out that the teacher explained the material and uploaded the material in Google Classroom for students who did not attend face-to-face learning (either in the classroom or video conferencing). The teachers prepare the material for the lesson in PDF format or PPT format, then upload it to Google Classroom. Then, the teacher informs this phase to the students into class WhatsApp group. Based on the observation results, the students must use their gadgets such as smartphones to access the Google Classroom to get the materials their teachers have sent.

In the interview section, teacher one said that they made the material into PDF or PPT format to make it easier for the students to learn. What made it challenging for the teacher was when a student asked through the WhatsApp group about the material uploaded in Google Classroom. Teacher one said he needed a lot of time to write answers, so he often uses voice notes when giving answers in WhatsApp groups.

Based on the observation results, the students sometimes have difficulties doing the tasks that their teacher has given. To solve the problem and fulfill the learners' needs, teachers provide a time for students who face difficulties in the class. They can ask questions related to the material that the teachers have taught. Teacher one said that it is important to give students an opportunity to have interaction with their teacher so that they can ask a question and get the answer from the material that has been explained. Also, in the interview section, teacher two said that teachers have to pay attention to the students' activities in the classes to know what the learners need in their learning process.

In online learning based on observation, the teacher prepares the material in a PDF or PPT format. After that, the teacher uploaded the material before the lesson began in the class WhatsApp group. The day before the English class, the teacher reminded the students that there would be face-to-face classes. Here the teacher would see the schedule of turns with other teachers, whether the English class that week would be done face-to-face virtually or face-toface in class which requires students to come to school. However, not all students were allowed to come to school due to health protocols during the pandemic. So, only fifty percent of the total number of students were allowed to join the face-to-face in-class meeting. 
From the observations, it can be seen that students who did face-to-face learning in class were very enthusiastic in participating in English class. They were also very interactive in answering the teacher's questions in the speaking class session. In the interview, the teacher also said that teaching English was easier when it was done face-to-face in class with students present. However, the teacher stated that the challenge was to facilitate students who had to study from home. This means that at the same time, the teacher must teach face-to-face and also prepare materials to be accessed by students on Google Classroom. It was difficult since it took longer and the teachers were frequently bored of performing it.

\section{TECHNOLOGICAL IN BLENDED LEARNING FOR TEACHING ENGLISH}

The technological aspects explain the tools that the teacher and the students use. The researchers found out that the teacher used technology and learning applications that can be found on the internet to support the online learning. The teacher used a laptop and a phone as the only devices connected to the internet. For the learning application, the school chose Google Classroom as the learning application that is a free service from Google for schools, especially for the teacher and the student. It helps teachers manage the learning process in online classes and provide performance appraisals more easily.

In face-to-face learning, schools use two methods: face-to-face in class, which requires students to come to school, and synchronous or virtual face-to-face learning using video conferencing applications, such as Zoom and Google Meet. In face-to-face learning practice, it did not mean that the teacher did not use the LMS application at all. Teachers still needed to access Google Classroom to upload material before face-to-face learning was carried out. This was done so that students who did not have their turn to come to school could learn from home. Then, students who came for face-to-face learning could learn the material. This also applied if the teacher conducts face-to-face learning virtually using Zoom or Google Meet. The teachers needed to upload the material first before the synchronous class so that the time used for the English class could be more effective because students were expected to read the previous material.

Based on the interviews, teacher one and teacher two stated that the technology offered by the school, such as the Zoom application and Google Meet, was beneficial for teachers in their teaching practice. The issue that became a challenge for teachers was using a shared Zoom account. So, they prefer to use Google Meet as an application for virtual face-to-face learning.

\section{INTERFACE DESIGN IN BLENDED LEARNING FOR TEACHING ENGLISH}

Interface design is how the teacher designs the teaching and learning process and the materials that combine technology and the internet. Based on observations, teachers only have technological devices such as smartphones and computers and use an internet connection to access applications for the online learning. However, teachers should still be creative in preparing their lessons. They should beautify the content of the English material itself and the appearance or interface design of the Google Classroom page or even the PPT that they make. For example, teachers can decorate the LMS display with pictures, animations, or attractive colors related to the content to increase students' interest in accessing it. In addition, the interface design can provide a pleasant experience for students with the appearance of the material presented by the teacher.

Unfortunately, English teachers do not fully design their interface pages for various reasons, such as a lack of time and experience in properly managing LMS. From the interviews, 
the teachers explained that this was their challenge to be creative with technology with limited tools.

In face-to-face classes in the classroom, the teacher does not do this phase. Despite the fact that they can design interfaces for materials uploaded to Google Classroom. well as virtual face-to-face learning, the teacher only displays PPT with a simple design. After the interview session with the researchers, the teachers realized that so far they had not realized that interface design needed to be done and that this would be their challenge in the future.

\section{RESOURCE SUPPORT IN BLENDED LEARNING FOR TEACHING ENGLISH}

For the resource support aspects, it explains the resources that the teacher and the students use and also the facilitating provided by the teacher in face-to-face and online learning. The researchers discovered that teachers utilized e-books as the primary reference in both face-toface and online learning. Teachers may also share internet resources with students to assist them in learning English. As a result, teachers are no longer restricted to using ICT (information, communication, and technology) instruments as the primary source of information in the classroom.

Based on the findings of the interviews, teachers one and two claimed that they prefer to utilize more than one source of information, such as books, and that they can combine the use of books and other online sources. As a result, they will make an effort to become acquainted with the many technologies that aid in the teaching and learning process. Teachers one and two occasionally use YouTube and Google Scholar papers to discuss content with students.

\section{MANAGEMENT IN BLENDED LEARNING FOR TEACHING ENGLISH}

The management of blended learning in this school shows that the infrastructure and strategies to help teachers in the classroom are good. Schools provide facilities, such as an internet connection, that they can use to complement their lessons. Teachers can access Google Classroom for online learning by connecting to the internet network. The school also authorizes students to use an internet connection to easily access Google Classroom through the school network. When learning online, teachers can manage their own learning. This is slightly different from face-to-face learning, especially if it is done offline in the school classroom. There is a schedule for each teacher, which means that not all students come unless it is their turn.

\section{THE TEACHER'S CHALLENGES IN IMPLEMENTING BLENDED LEARNING IN ENGLISH TEACHING AT SENIOR HIGH SCHOOL PORONG SIDOARJO}

When the school implements Blended Learning in teaching English, the teacher faces challenges in the teaching process. They convey these challenges to the researcher in collecting interview data. Teacher one and teacher two almost have the same opinion on delivering the challenges that they faced. Teacher One said that using Blended Learning in teaching English has difficulties for them. The difficulty is that it is hard to know if the student already understands the material or not. Especially in online learning, where there is no direct communication between the teacher and the students, the school only uses Google Classroom in the teaching and learning process. As a result, teacher one discovered that it is one of the difficulties in teaching English through blended learning. Teacher One tries to face the 
challenge of keeping paying attention to student development during online learning by paying attention to each task given, and providing exercises as a test of their understanding of the material that has been delivered. Also, teacher one facilitates the students' having a private class outside of the school activities. In order to give them an explanation of the material that they find difficult to understand, Teacher one stated that knowing their progress will make them happy while teaching English. The solution that the teacher finds is to keep in touch by having direct communication with the student in the school or on-line chat.

Almost the same as teacher one, teacher two also faced challenges in teaching English using blended learning. Teacher two said in the interview section, it is really strange to teach without seeing them face-to-face because it is hard to know if the student already understands the material or not, what the student's responsibility is in answering our questions, and how they behave during the learning process. Using Google Classroom is one of the causes of the learning process, which makes it difficult to know the development of the student in online learning. Teacher two said that is the challenge for teachers, which we should be able to figure out on our own. Teacher two also said we should be able to get used to interacting more often with students to know the student's development and characteristics.

\section{DISCUSSION}

Blended learning is a learning strategy where the face-to-face learning process in class (traditionally in class or synchronously) is combined with the e-learning process using LMS such as Google Classroom and Moodle. Based on the results of data analysis in this study, the implementation of blended learning in English classes is full of challenges during the pandemic. Teachers struggle to harmonize information and learning media to support the implementation of blended learning. According to Sagala (2006), the use of various information and media by teachers in the classroom can increase students' enthusiasm to participate in the learning process, both face-to-face and online in blended learning.

This study aligns with previous research that found blended learning to be effective in helping students learn English (Ma'rifatulloh, 2020). However, there are also other factors that can influence the success of implementing blended learning, especially in learning English in schools. These factors, such as conditions, environment, demographics, characteristics of students and teachers, can affect the implementation of blended learning. In addition, according to Khan (2010), there are five components that need to be considered in blended learning, such as pedagogical, technological, interface design, resource support, and management. Schools and teachers should manage the five components well in order to ensure that students continue to learn during the COVID-19 pandemic.

\section{CONCLUSION}

In a nutshell, the results showed that although blended learning in teaching English went well, both teachers and students had challenges in implementing blended learning. This study concludes that teachers and students have the same opinion. They both prefer face-to-face learning over e-learning. The reason is that face-to-face learning allows teachers and students to communicate directly, which improves both student-teacher relationships and students' capacity to communicate with others. Both traditionally and virtually, face-to-face learning also allows teachers to interact with students more naturally, such as asking questions in class and asking students to respond. However, blended learning is an ideal strategy to deal with teaching and learning problems in the modern era, where teachers can still meet face-to-face 
when they have to teach their students. However, teachers are also expected to continue to improve their abilities and creativity when conducting online learning activities to be more innovative in teaching. The results of this study cannot be generalized solely to learning in other fields. Therefore, the researchers recommend that further research look at blended learning in other fields of education and with the latest theories.

\section{ACKNOWLEDGEMENT}

This research is a part of the undergraduate thesis. The author would like to express her gratitude to her supervisor for her help, as well as to the Universitas Muhammadiyah Sidoarjo, which became the author's place of study.

\section{REFERENCES}

Adi, S., \& Fathoni, A. F. (2020). Blended learning analysis for sports schools in Indonesia. International Journal of Interactive Mobile Technologies, 14(12), 149-164. https://doi.org/10.3991/IJIM.V14I12.15595

Alsalhi, N. R., Eltahir, M. E., \& Al-Qatawneh, S. S. (2019). The effect of blended learning on the achievement of ninth grade students in science and their attitudes towards its use. Heliyon, 5(9), e02424. https://doi.org/10.1016/j.heliyon.2019.e02424

Carman, J. M. (2002). Blended learning design. October.

Chew, E., Jones, N., \& Turner, D. (2008). Critical review of the blended learning models based on Maslow's and Vygotsky's educational theory. Lecture Notes in Computer Science (Including Subseries Lecture Notes in Artificial Intelligence and Lecture Notes in Bioinformatics), 5169 LNCS(August), 40-53. https://doi.org/10.1007/978-3-54085170-7_4

Christopoulos, A., \& Sprangers, P. (2021). Integration of educational technology during the Covid-19 pandemic: An analysis of teacher and student receptions. Cogent Education, 8(1). https://doi.org/10.1080/2331186X.2021.1964690

Crawford, R., \& Jenkins, L. (2017). Blended learning and team teaching: Adapting pedagogy in response to the changing digital tertiary environment. Australasian Journal of Educational Technology, 33(2), 51-72. https://doi.org/10.14742/ajet.2924

Creswell, J. W., Hanson, W. E., Clark Plano, V. L., \& Morales, A. (2007). Qualitative Research Designs: Selection and Implementation. The Counseling Psychologist, 35(2), 236-264. https://doi.org/10.1177/0011000006287390

Dziuban, C., Graham, C. R., Moskal, P. D., Norberg, A., \& Sicilia, N. (2018). Blended learning: the new normal and emerging technologies. International Journal of Educational Technology in Higher Education, 15(1), 1-16. https://doi.org/10.1186/s41239-017-0087-5

Evain, C., \& Marco, C. De. (2018). The eZoomBook Tool: A Blended and Eclectic Approach to Digital Pedagogy. Journal of Education and Training Studies, 6(8), 139. https://doi.org/10.11114/jets.v6i8.3428

Galvis, Á. H. (2018). Supporting decision-making processes on blended learning in higher education: literature and good practices review. International Journal of Educational Technology in Higher Education, 15(1), 1-38. https://doi.org/10.1186/s41239-0180106-1

Husamah. (2014). Pembelajaran Bauran (Blended Learning) Terampil Memadukan 
Keunggulan Pembelajaran Face-to-face, E-learning Offline-Online dan Mobile Learning.

Khan, B. H. (2010). The global e-learning framework. 42-51.

Kumar, A., Krishnamurthi, R., Bhatia, S., Kaushik, K., Ahuja, N. J., Nayyar, A., \& Masud, M. (2021). Blended Learning Tools and Practices: A Comprehensive Analysis. IEEE Access, 9, 85151-85197. https://doi.org/10.1109/ACCESS.2021.3085844

Ma'rifatulloh, S. (2020). Measuring the Impact of Blended Learning in EFL Classroom. Proceedings of the 1st International Conference on Islamic Civilization, ICIC 2020,.

Menon, S. A. (2019). Designing Online Materials for Blended Learning: Optimising on BookWidgets. InternationalJournal of Linguistics, Literature and Translation, 2(3), 166-174. https://doi.org/10.32996/ijllt.2019.2.3.19

Susanti, D. I., \& Prameswari, J. Y. (2020). Adaptasi Blended Learning di Masa Pandemi COVID-19 untuk Pembelajaran Bahasa Inggris di Sekolah Dasar. 1(2), 50-61.

Syaiful Sagala. (2006). Konsep dan makna pembelajaran. Bandung: CV. Alfabeta.

Tayebinik, M., \& Puteh, M. (2013). Blended Learning or E-learning?

Zhang, R. (2020). Exploring blended learning experiences through the community of inquiry framework. Language Learning and Technology, 24(1), 38-53.

https://doi.org/10.125/44707 